\title{
Identification of Promising Genotypes and Discriminating Traits under Salt Stress at Early Growth Stages of Maize
}

\author{
Muhammad Aslam $^{1 *}$, Muhammad Amir Maqbool ${ }^{2}$, Sarfraz Ahmad ${ }^{1}$, Waseem Akbar ${ }^{3}$, Muhammad Arslan Akhtar ${ }^{1}$ \\ and Ayesha Aslam ${ }^{1}$ \\ ${ }^{1}$ Department of Plant Breeding and Genetics, University of Agriculture Faisalabad, Pakistan \\ ${ }^{2}$ International Maize and Wheat Improvement Center (CIMMYT), Pakistan \\ ${ }^{3}$ Maize and Millets Research Institute (MMRI), Yousafwala, Sahiwal, Pakistan \\ *For correspondence: aslampbg@gmail.com
}

Received 28 September 2017; Accepted 03 May 2021; Published 10 June 2021

\begin{abstract}
Salinity stress is one of the leading abiotic stresses seriously affecting the crop productivity across the world. Early growth stages are more affected by salinity stress than terminal growth stages. Therefore, maize genotypes were evaluated for their performance in three different studies (Experiment-1: irrigation of seeds with salt solutions (distilled water, $4 \mathrm{dS} / \mathrm{m}, 6 \mathrm{dS} / \mathrm{m}$ and $10 \mathrm{dS} / \mathrm{m}$ ) for 5 days, Experiment-2: application of different salinity treatments (distilled water, $4 \mathrm{dS} / \mathrm{m}, 6 \mathrm{dS} / \mathrm{m}$ and 10 $\mathrm{dS} / \mathrm{m}$ ) for 20 days from sowing to seedling emergence stage, Experiment-3: application of salinity stresses in hydroponic culture under four above mentioned different salinity treatments. Time to start germination (TSG), time to 50\% germination (TFG) and final germination percentage (FGP) of the maize genotypes was reduced by salinity stress. Radicle length, plumule length, root and shoot length and fresh weight and chlorophyll contents were also linearly reduced in maize genotypes by increasing salinity levels. Moreover, sodium $\left(\mathrm{Na}^{+}\right)$concentration was increased in seeds and seedlings of maize genotypes whereas; potassium $\left(\mathrm{K}^{+}\right)$concentration was reduced with gradual rise in salinity levels. Principal Component Analysis (PCA) biplots facilitated the efficient assortment of susceptible, moderately susceptible, moderately tolerant and tolerant maize genotypes for each of the three studies separately. Genotype 'YS-2008' was susceptible for seed treatment and hydroponic studies whereas, genotype 'T267-5' was susceptible for early seedling and hydroponic studies. Genotype 'C864-284' was tolerant in early seedling and hydroponic studies. The GGE biplot analysis indicated that 'YS-2008' genotype was susceptible for salinity stress. Under hydroponic conditions, genotypes could effectively be discriminated by the imposition of severe salt stress $(10 \mathrm{dS} / \mathrm{m})$; however, under seed treatments and early seedling growth stages, mild stress treatments $(4 \mathrm{dS} / \mathrm{m})$ were sufficient enough to discriminate the maize genotypes. Hydroponic evaluation of genotypes is suitable and preferable under high stress conditions at early growth stages. Identified tolerant and susceptible genotypes could be effectively used in different breeding programs to develop salt tolerant new cultivars for commercial purposes. (C) 2021 Friends Science Publishers
\end{abstract}

Keywords: GGE biplot; PCA biplot; $\mathrm{Na}^{+}$concentration; $\mathrm{K}^{+}$concentration; Hydroponic culture; Seed treatment

\section{Introduction}

In Pakistan, maize (Zea mays L.) is an important cereal crop as it ranks $3^{\text {rd }}$ after wheat (Triticum aestivum L.) and rice (Oryza sativa L.). Maize being highly polymorphic contains high genetic variability. Maize contributes $2.9 \%$ to value addition in agriculture and $0.6 \%$ to gross domestic production (GDP). During 2019-20, maize crop was grown on about 1.4 million hectares with total production of 7.2 million tons and average yield of 5.1 tons ha ${ }^{-1}$ (ESP 20192020).

Pakistan has 80 million hectares area out of which 19.3 Mha is for agriculture and 6.30 Mha of that is salt affected soils. Area under salt affected soil is increasing at the rate of 40,000 ha annually (Nawaz 2007). The hydrological balance of irrigated areas is disturbed by continuous use of surface irrigation and poor land management.

Salinity is one of the leading abiotic stresses in the country. Pakistan is located in arid and semi-arid regions where climate is of subtropical nature and process of sodification and salinization is continuously in progress. Excessive soil salt is adversely affecting the biological, chemical and physical properties of soil. These changes resultantly affecting the plant roots, crop growth \& development and yield. It is important to bring the saltaffected soil under proper cultivation through different means to ensure the food security (Hussain et al. 2018; Syed et al. 2021).

Maize is moderately sensitive to salt stress due to $\mathrm{C} 4$ metabolism. It is reported by researchers that salt stress and 
drought stress can severely damage the maize plants in form of stunted growth and severe wilting (Farooq et al. 2015; Ul-Allah et al. 2020). Toxicity of salt stress is mainly caused by sodium ion, which is interfering with uptake of potassium and resultantly stomatal opening is disturbed causing serious water losses, and necrosis in maize (Turan et al. 2009; Farooq et al. 2015). Increased concentration of $\mathrm{Na}^{+}$reduces the $\mathrm{K}^{+}$uptake by entering cells of plant, leads to $\mathrm{Na}$ : $\mathrm{K}$ ratio imbalance in the cells. The $\mathrm{K}^{+}$uptake reduces in cells due to closure of $\mathrm{K}^{+}$channel by membrane potential (Gao et al. 2016). Shahzad et al. (2012) also reported a decline in $\mathrm{K}$ contents in leaf symplast of maize under salt stress. Reduction in growth and yield of maize was also observed under salt stress (Gao et al. 2016). The exploitation of genetic variability in available germplasm is important to identify a tolerant genotype that may give a reasonable yield on salt affected soils (Farooq et al. 2015). To develop salt tolerant varieties, it is necessary to identify salt tolerant germplasm by screening of large number of genotypes of crop (Acosta-Motos et al. 2017).

The germination of seed is affected by high concentration of salts (Rahman et al. 2000). Seed germination is one of the critical stages in seedling establishment and determinant of successful crop production under salt stress (Ashraf and Foolad 2005; Farsiani and Ghobadi 2009). It is also important to mention that germination and early growth stages are more sensitive to salt stress than terminal growth stages (Farooq et al. 2015, 2017). The rate and percentage of seed germination is reduced by salinity, which in turn leads to reduce crop yields (Foolad and Lin 2001). Sodium ion toxicity and osmotic stress are cumulatively affecting the seed germination and early growth stages (Farsiani and Ghobadi 2009; Hussain et al. 2013, 2018).

Plants developed a wide range of adaptive/resistant mechanisms to maintain productivity and to ensure the survival under salt stress. Salinity resistance in plants can be enhanced by regulation of mineral nutrients. Potassium has a particular role in maintaining plant survival under salt stress (Mengel and Kirkby 2001). Although use of different soil amendments or reclamation strategies is in practice but exploration salt tolerant cultivars are one of the sustainable approaches to improve productivity of saline areas. Therefore, to utilize the salt affected land, it is important to identify the promising maize genotypes which could counteract salt stress. Hence, present study was planned with following key research objectives: (1) evaluation of diverse maize genotypes under wide range of salt stress treatments to identify the promising genotypes, (2) to determine the changes in $\mathrm{Na}^{+}$and $\mathrm{K}^{+}$concentrations of maize genotypes under various stress treatments, (3) Identification of discriminating stress treatment under various experiments.

\section{Materials and Methods}

Present study was conducted in laboratory and research area of Department of Plant Breeding and Genetics (PBG), University of Agriculture, Faisalabad (UAF) during 2017. Germplasm was collected from different Public and Private Institutes working on maize research and development. Following 20 maize genotypes were used in present study: T047-1-T186-1, T312-14, T330-10, C863-68, T267-5, T267-6, T283-30, SEEDCO, T312-11, T323-190, T-330-1, C863-109, T312-12, T322-195, C864-228, C864-237, T267-7, T330-25, C864-248 and YS-2008. Present study comprised of three different experiments. Thorough evaluation of maize genotypes under salt stress requires response estimation from seed uptake, seedling growth and seedling establishment at early growth stages. Different set of parameters are performance indicators in components studies; therefore, different experiments were designed. So, this study was comprised of three experiments in which maize genotypes were evaluated against salinity stress at seed uptake, seedling growth in petri plates and seedling establishment in hydroponic culture.

\section{Experiment 1: evaluation of $\mathrm{Na}^{+}$and $\mathrm{K}^{+}$ions in salt treated maize seeds}

In $1^{\text {st }}$ experiment, five maize seeds of 20 maize genotypes (names mentioned above) were sown in each petri plates (60 $\mathrm{mm} \times 15 \mathrm{~mm})$ separately in three replicated. Experimental design followed was completely randomized design with factorial treatment structure. Treatments containing different concentrations of $\mathrm{NaCl}$ (distilled water, $4 \mathrm{dS} / \mathrm{m}, 6 \mathrm{dS} / \mathrm{m}$ and $10 \mathrm{dS} / \mathrm{m}$ ) were applied for 5 days.

The data for $\mathrm{Na}^{+}\left(\mathrm{mol} / \mathrm{m}^{3}\right)$ concentration and $\mathrm{K}^{+}$ $\left(\mathrm{mol} / \mathrm{m}^{3}\right)$ concentration of the maize seeds was measured by collecting the seed samples from respective petri plates.

\section{Estimation of $\mathrm{Na}^{+}$and $\mathrm{K}^{+}$concentration}

After five days of maize seed sown in different $\mathrm{NaCl}$ treatments, the seeds were dried in room temperature for 45 days and then oven dried. Oven dried seeds were grinded with electric machine and digestion was made in fume hood by following the Wolf (1982) method. The digested material was diluted with distilled water according to the requirement. Sherwood 410 flame photometer was used for estimation of both $\mathrm{Na}^{+}$and $\mathrm{K}^{+}$concentration. $\mathrm{Na}^{+}$ concentrations were measured with the help of self-prepared standard solutions using reagent grade $\mathrm{NaCl}$ salt. However, $\mathrm{K}^{+}$concentration was measured by using the self-prepared standard solutions using reagent grade $\mathrm{KCl}$ salt.

\section{Experiment 2: seedling evaluation in petri plates}

In this experiment five maize seed of 20 genotypes (names given above) were sown in each petri plate $(100 \mathrm{~mm} \times 15$ $\mathrm{mm})$ separately. Following treatments containing different concentrations of $\mathrm{NaCl}$ (distilled water, $4 \mathrm{dS} / \mathrm{m}, 6 \mathrm{dS} / \mathrm{m}$ and $10 \mathrm{dS} / \mathrm{m}$ ) were applied for 20 days. 
Experiment was laid out by following completely randomized design (CRD) with three replicates for each genotype under factorial treatment structure. The data for following germination related parameters was measured; time to start germination (TSG; days), time to $50 \%$ germination (TFG; $\mathrm{T}_{50}$ ), final germination percentage (FGP), radicle length (RadL; $\mathrm{cm}$ ), plumule length (PluL; $\mathrm{cm}), \mathrm{Na}^{+}$ $\left(\mathrm{mol} / \mathrm{m}^{3}\right)$ concentration and $\mathrm{K}^{+}\left(\mathrm{mol} / \mathrm{m}^{3}\right)$ concentration of germinated seedlings including the plumule part.

Numbers of germinated seeds were recorded on daily basis by following the method given in seedling evaluation Handbook of Association of Official Seed Analysts (1990). Following formulae of Coolbear et al. (1984) modified by Farooq et al. (2005) was used to calculate the time taken to $50 \%$ germination $\left(\mathrm{TFG} ; \mathrm{T}_{50}\right)$.

$$
T_{50}=t_{i}+\left[\frac{N / 2-n_{i}}{n_{j}-n_{i}}\right]\left(t_{j}-t_{i}\right)
$$

where, $\mathrm{N}$ is the number of final germination count and $\mathrm{n}_{\mathrm{i}}, \mathrm{n}_{\mathrm{j}}$ cumulative number of seeds emerged at adjacent days $t_{i}$ and $t_{j}$ when $n_{i}<(N+1) / 2<n_{j}$.

Final germination percentage is the ratio, in percentage, of number of germinated seeds to total seeds planted following method of ISTA (2008).

$$
\text { FGP }=\frac{\text { Number of germinated seeds }}{\text { Total number of seeds sown }} \times 100
$$

For determination of $\mathrm{Na}^{+}$and $\mathrm{K}^{+}$concentration, dried shoots were grinded with electric grinder and digestion was done in fume hood by Wolf (1982) method. The digested material was diluted with distilled water according to requirement and by using Sherwood 410 flame photometer with the help of self-prepared standard solutions using reagent grade salts $\mathrm{NaCl}$ and $\mathrm{KCl}, \mathrm{Na}^{+}\left(\mathrm{mol} / \mathrm{m}^{3}\right)$ and $\mathrm{K}^{+}$ $\left(\mathrm{mol} / \mathrm{m}^{3}\right)$ concentrations were recorded.

\section{Experiment 3: hydroponic evaluation of maize genotypes under salt stress}

Healthy seeds of each of 20 genotypes (names are given above) were sown in iron trays to raise seedlings. Sand was pre-soaked with water before used as growth medium. Tap water $(\mathrm{EC} \leq 2)$ was used for irrigation. At three leave stage seedlings were shifted into hydroponic cultures. Hydroponic study was conducted in water tanks in which aeration was provided through air pumps and nutrients were provided in the form Hoagland solution. Micro and macro nutrients were used as supplements according to the recommendations (Hoagland and Arnon 1950). Polystyrene sheets floating over $1 / 2$ strength Hoagland's nutrient solution (Hoagland and Arnon 1950) were used as plant supporting medium. Proper aeration in solution was provided by aeration pumps. After two days of nursery transplanting in hydroponic culture four salinity levels (tap water, $4 \mathrm{dS} / \mathrm{m}, 6$
$\mathrm{dS} / \mathrm{m}$ and $10 \mathrm{dS} / \mathrm{m})$ as described for previous experiments were developed with $\mathrm{NaCl}$. The $\mathrm{pH}$ of the solution was maintained on alternate days with the help of $\mathrm{pH}$ meter (Jenwey-model 4070). After 20 days of treatment application, seedlings were harvested manually and data were recorded for; shoot length (SL; cm), root length (RL; $\mathrm{cm}$ ), shoot fresh weight (SFW; g), root fresh weight (RFW; $\mathrm{g}$ ), total seedling biomass (TPB; g), leaf temperature (LT; $\left.{ }^{\circ} \mathrm{C}\right)$, leaf chlorophyll contents $\left(\mathrm{ChC} ; \mu \mathrm{mol} / \mathrm{m}^{2}\right), \mathrm{Na}^{+}$ concentration $\left(\mathrm{mol} / \mathrm{m}^{3}\right), \mathrm{K}^{+}$concentration $\left(\mathrm{mol} / \mathrm{m}^{3}\right), \mathrm{Na}^{+} / \mathrm{K}^{+}$ ratio in shoots. Leaf temperature was quantified with RAYRPM30CFTRG ${ }^{\circledR}$ thermometer. Leaf chlorophyll contents were measured with chlorophyll meter whereas; $\mathrm{Na}^{+}$and $\mathrm{K}^{+}$concentration of maize shoots was measured by using the same method as mentioned in Experiment-1.

\section{Statistical analysis}

Acquired data from three different studies were subjected to two-way analysis of variance (ANOVA) with factorial treatment structure (Steel et al. 1997). Treatment mean comparisons were accomplished by using the line graph and bar graphs. Analysis of variance was done with Statistix 8.1 software, whereas line graphs and bar graphs were prepared in MS Excel sheet. PCA biplot (Gabriel 1971) and GGE biplot (Yan and Tinker 2006) analysis were used as multivariate analysis for evaluation of the genotypic responses. Genstat13 software used for making PCA biplots and GGE biplots.

\section{Results}

Results from all of three different experiments were separately elaborated, and then these were compared.

\section{Analysis of variance}

In first experiment, very critical traits viz., $\mathrm{Na}^{+}\left(\mathrm{mol} / \mathrm{m}^{3}\right), \mathrm{K}^{+}$ $\left(\mathrm{mol} / \mathrm{m}^{3}\right)$ and $\mathrm{Na}^{+} / \mathrm{K}^{+}$were measured from treated seeds. Analysis of variance for these traits depicted that there were highly significant differences in the salinity treatments, genotypic responses and genotype $\times$ treatment interaction effects for these three pivotal traits (Table 1). Second experiment comprised of eight different traits like, TSG, TFG, FGP, RadL, PluL, $\mathrm{Na}^{+}, \mathrm{K}^{+}$and $\mathrm{Na}^{+} / \mathrm{K}^{+}$. ANOVA for these traits showed the highly significant differences in the salinity treatments, genotypic responses and genotype $\times$ treatment interaction effects for all of these seven traits (Table 1). Third experiment comprised of 10 different morphological and biochemical traits viz., SL, RL, SFW, RFW, TPB, LT, ChC, $\mathrm{Na}^{+}$and $\mathrm{K}^{+}$concentrations in seedlings and $\mathrm{Na}^{+} / \mathrm{K}^{+}$. ANOVA showed the highly significant difference in the salinity treatments, genotypic responses and genotype $\times$ treatment interaction effects for all of these nine morphological and physiological traits (Table 1). 
Aslam et al. / Intl J Agric Biol, Vol 26, No 1, 2021

Table 1: Analysis of variance for different traits of maize under different salinity stress treatment

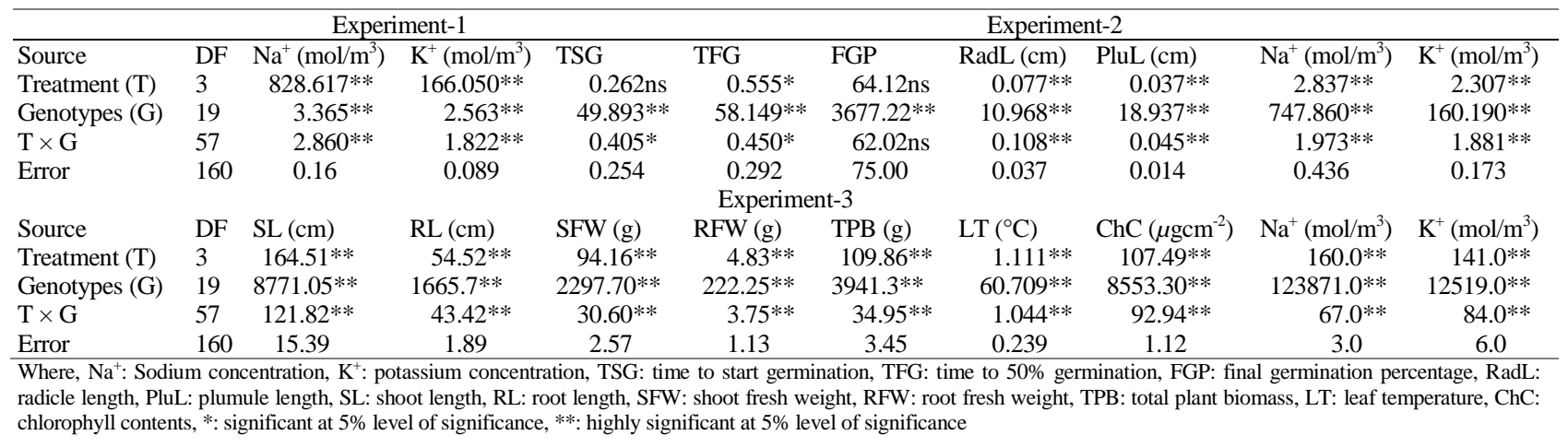

Table 2: Treatment mean comparison for $\mathrm{Na}^{+}\left(\mathrm{mol} / \mathrm{m}^{3}\right), \mathrm{K}^{+}\left(\mathrm{mol} / \mathrm{m}^{3}\right)$ concentration and $\mathrm{Na}^{+} / \mathrm{K}^{+}$ratio in all of three experiments

\begin{tabular}{|c|c|c|c|c|c|c|c|c|c|}
\hline Treatments & & speriment-1 & & & xperiment-2 & & & xperiment-3 & \\
\hline & $\mathrm{Na}^{+}\left(\mathrm{mol} / \mathrm{m}^{3}\right)$ & $\mathrm{K}^{+}\left(\mathrm{mol} / \mathrm{m}^{3}\right)$ & $\mathrm{Na}^{+} / \mathrm{K}^{+}$ & $\mathrm{Na}^{+}\left(\mathrm{mol} / \mathrm{m}^{3}\right)$ & $\mathrm{K}^{+}\left(\mathrm{mol} / \mathrm{m}^{3}\right)$ & $\mathrm{Na}^{+} / \mathrm{K}^{+}$ & $\mathrm{Na}^{+}\left(\mathrm{mol} / \mathrm{m}^{3}\right)$ & $\mathrm{K}^{+}\left(\mathrm{mol} / \mathrm{m}^{3}\right)$ & $\mathrm{Na}^{+} / \mathrm{K}^{+}$ \\
\hline Distilled water & $8.77 \mathrm{~d}$ & $10.91 \mathrm{a}$ & $0.81 \mathrm{~d}$ & $9.98 \mathrm{~d}$ & $11.61 \mathrm{a}$ & $0.87 \mathrm{~d}$ & $30.87 \mathrm{~d}$ & $136.28 \mathrm{a}$ & $0.23 \mathrm{~d}$ \\
\hline $4 \mathrm{dS} / \mathrm{m}$ & $11.24 \mathrm{c}$ & $10.09 \mathrm{~b}$ & $1.12 \mathrm{c}$ & $11.85 \mathrm{c}$ & $10.55 \mathrm{~b}$ & $1.13 \mathrm{c}$ & $39.38 \mathrm{c}$ & $120.0 \mathrm{~b}$ & $0.33 \mathrm{c}$ \\
\hline $6 \mathrm{dS} / \mathrm{m}$ & $14.44 \mathrm{~b}$ & $8.67 \mathrm{c}$ & $1.68 \mathrm{~b}$ & $15.18 \mathrm{~b}$ & $9.16 \mathrm{c}$ & $1.67 \mathrm{~b}$ & $83.40 \mathrm{~b}$ & $83.40 \mathrm{c}$ & $0.99 \mathrm{~b}$ \\
\hline $10 \mathrm{dS} / \mathrm{m}$ & $17.29 \mathrm{a}$ & $7.12 \mathrm{~d}$ & $2.45 \mathrm{a}$ & $17.94 \mathrm{a}$ & $7.86 \mathrm{~d}$ & $2.29 \mathrm{a}$ & $129.79 \mathrm{a}$ & $33.32 \mathrm{~d}$ & $4.01 \mathrm{a}$ \\
\hline LSD value at $1 \%$ & 0.04 & 0.02 & 0.01 & 0.49 & 0.20 & 0.01 & 2.08 & 4.16 & 0.01 \\
\hline
\end{tabular}

Means with different letters within a column for each trait are statistically different from each other at $\mathrm{p} 0.01$

Where, distilled water: distilled water was applied, $4.00 \mathrm{dS} / \mathrm{m}$ : salinity treatment of $4.00 \mathrm{dS} / \mathrm{m}, 6.00 \mathrm{dS} / \mathrm{m}$ : salinity treatment of $6.00 \mathrm{dS} / \mathrm{m}, 10.00 \mathrm{dS} / \mathrm{m}$ : salinity treatment of 10.00 $\mathrm{dS} / \mathrm{m}$, LSD: least significant difference, Expriment-1, 2 \& 3: description is given in materials and methods

Table 3: Treatment mean comparison for various germination and seedling related traits of maize genotypes

\begin{tabular}{|c|c|c|c|c|c|c|c|c|c|c|c|c|}
\hline \multirow[t]{2}{*}{ Treatments } & \multicolumn{5}{|c|}{ Experiment-2 } & \multicolumn{7}{|c|}{ Experiment-3 } \\
\hline & TSG & TFG & FGP & RadL & PluL & SL & $\mathrm{RL}$ & SFW & RFW & TPB & LT & ChlC \\
\hline Distilled water & $4.7 \mathrm{~d}$ & $5.7 \mathrm{~d}$ & 94 & $4.6 \mathrm{a}$ & $3.7 \mathrm{a}$ & $79.10 \mathrm{a}$ & $32.80 \mathrm{a}$ & $27.80 \mathrm{a}$ & $9.20 \mathrm{a}$ & $37.0 \mathrm{a}$ & $30.2 \mathrm{~d}$ & $36.8 \mathrm{a}$ \\
\hline $4 \mathrm{dS} / \mathrm{m}$ & $5.5 \mathrm{c}$ & $6.4 \mathrm{c}$ & 86 & $4.5 \mathrm{~b}$ & $2.9 \mathrm{~b}$ & $63.00 \mathrm{~b}$ & $31.10 \mathrm{~b}$ & $22.70 \mathrm{~b}$ & $7.30 \mathrm{~b}$ & $30.0 \mathrm{~b}$ & $31.5 \mathrm{c}$ & $34.8 \mathrm{~b}$ \\
\hline $6 \mathrm{dS} / \mathrm{m}$ & $6.1 \mathrm{~b}$ & $7.3 \mathrm{~b}$ & 82 & $4.4 \mathrm{c}$ & $2.6 \mathrm{c}$ & $56.60 \mathrm{bc}$ & $25.20 \mathrm{c}$ & $17.40 \mathrm{c}$ & $5.60 \mathrm{c}$ & $23.0 \mathrm{c}$ & $32.4 \mathrm{a}$ & $17.7 \mathrm{c}$ \\
\hline $10 \mathrm{dS} / \mathrm{m}$ & $6.8 \mathrm{a}$ & $7.9 \mathrm{a}$ & 75 & $3.6 \mathrm{~d}$ & $2.3 \mathrm{~d}$ & $51.20 \mathrm{~cd}$ & $21.40 \mathrm{~d}$ & $13.60 \mathrm{~d}$ & $4.80 \mathrm{~d}$ & $8.50 \mathrm{~d}$ & $32.3 \mathrm{ab}$ & $13.2 \mathrm{~d}$ \\
\hline LSD value at $1 \%$ & 0.18 & 0.20 & NS & 0.03 & 0.01 & 10.66 & 1.34 & 1.79 & 0.78 & 2.39 & 0.17 & 0.78 \\
\hline
\end{tabular}

Means with different letters within a column for each trait are statistically different from each other at $P 0.01$

Where, TSG: time to start germination (days), TFG: time to complete 50\% germination (days), FGP: final germination percentage (\%), RadL: radicle length (cm), PluL: plumule length $(\mathrm{cm})$, SL: shoot length (cm), RL: root length (cm), SFW: shoot fresh weight (g), RFW: root fresh weight (g), TPB: total plant biomass (g), LT: leaf temperature (C), ChlC:

chlorophyll contents $\left(\mu \mathrm{mol} / \mathrm{m}^{2}\right)$, LSD: least significant difference, NS: Non-significant, Experiment-2 \& 3: description is given in materials and methods

\section{Treatment means comparison}

Treatment mean comparison with key focus on $\mathrm{K}^{+}, \mathrm{Na}^{+}$and $\mathrm{Na}^{+} / \mathrm{K}^{+}$were presented as line graphs and bar graphs. In experiment- $1, \mathrm{Na}^{+}$concentration was depicting the increasing trend as moving from distilled water to $10 \mathrm{dS} / \mathrm{m}$ where, $\mathrm{Na}^{+}$concentration was $8.77 \mathrm{~mol} / \mathrm{m}^{3}$ under $4 \mathrm{dS} / \mathrm{m}$ and $17.29 \mathrm{~mol} / \mathrm{m}^{3}$ under $10 \mathrm{dS} / \mathrm{m}$ respectively based on the average of all studied genotypes. $\mathrm{K}^{+}$concentration was $10.91 \mathrm{~mol} / \mathrm{m}^{3}$ at distilled water application which was reduced to $7.12 \mathrm{~mol} / \mathrm{m}^{3}$ at $10 \mathrm{dS} / \mathrm{m} . \mathrm{Na}^{+} / \mathrm{K}^{+}$was 0.81 at distilled water which was increased to 2.45 at $10 \mathrm{dS} / \mathrm{m}$ (Table 2). In Experiment-2, $\mathrm{Na}^{+}$concentration was depicting the increasing trend whereas $\mathrm{K}^{+}$concentration was showing the decreasing trend as moving from distilled water to 10 $\mathrm{dS} / \mathrm{m}$. Na ${ }^{+}$concentration was $9.98 \mathrm{~mol} / \mathrm{m}^{3}$ under distilled water and $17.94 \mathrm{~mol} / \mathrm{m}^{3}$ under $10 \mathrm{dS} / \mathrm{m}$ based on the average performance of all studied genotypes. $\mathrm{K}^{+}$concentration was $11.51 \mathrm{~mol} / \mathrm{m}^{3}$ at distilled water which was reduced to 7.86 $\mathrm{mol} / \mathrm{m}^{3}$ at $10 \mathrm{dS} / \mathrm{m}$. Na ${ }^{+} / \mathrm{K}^{+}$was 0.87 at distilled water which was increased to 2.29 at $10 \mathrm{dS} / \mathrm{m}$ (Table 2).
In Experiment-3, there was decreasing trend for $\mathrm{K}^{+}$ concentration and increasing trend for $\mathrm{Na}^{+}$concentration with increase of salinity stress but relative contents of $\mathrm{Na}^{+}$ and $\mathrm{K}^{+}$minerals were higher than previous two experiments. $\mathrm{Na}^{+}$concentration was $30.87 \mathrm{~mol} / \mathrm{m}^{3}$ under distilled water which was increased to $129.78 \mathrm{~mol} / \mathrm{m}^{3}$ under $10 \mathrm{dS} / \mathrm{m} . \mathrm{K}^{+}$concentration was $136.28 \mathrm{~mol} / \mathrm{m}^{3}$ at distilled water which was reduced to $33.32 \mathrm{~mol} / \mathrm{m}^{3}$ at $10 \mathrm{dS} / \mathrm{m}$. At 6 $\mathrm{dS} / \mathrm{m}$ both $\mathrm{Na}^{+}$and $\mathrm{K}^{+}$concentrations were almost equivalent based on average of all of the studied genotypes (Table 2). Mean comparison for other traits from experiment- 2 and experiment- 3 were presented in the Table 3 which is clearly highlighting the pattern of responses.

\section{Principal component analysis (PCA) biplots}

Principal component based biplot analysis was for pictorial view of genotypic performance across the different experiments and different treatments of same experiments. All of the four salinity treatments from all of the three different experiments were separately analyzed by PCA 

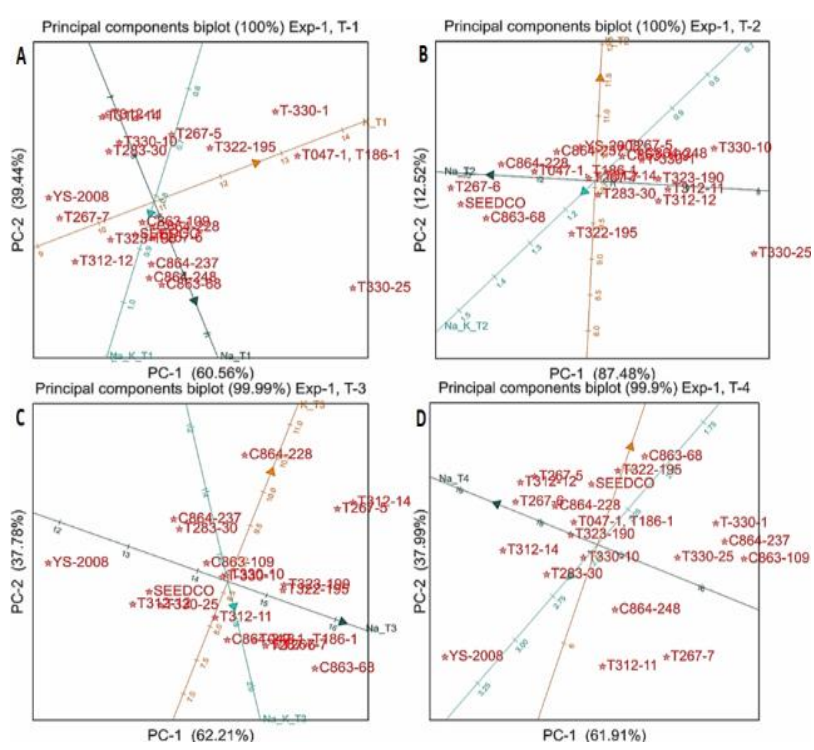

Fig. 1: PCA biplot analysis of different salinity treatments applied at seed imbibition stage in different maize genotypes (Experiment-1). (A): T-1 (distilled water), (B): T-2 (4 dS/m), (C): T-3 (6 dS/m), (D): T-4 (10 dS/m). Where, $\mathrm{Na}^{+}$: sodium concentration $\left(\mathrm{mol} / \mathrm{m}^{3}\right), \mathrm{K}^{+}$: potassium concentration $\left(\mathrm{mol} / \mathrm{m}^{3}\right)$, $\mathrm{Na}^{+} / \mathrm{K}^{+}$sodium potassium ratio

biplot analysis. PCA biplot for distilled water from experiment-1 depicted the 100\% (PC-1: 60.56\%, PC-2: $39.44 \%$ ) variability of data from subjected traits. Wider angle of the trait vectors showed that traits were widely different in explaining the performance of genotypes. Traits vectors in the PCA biplots were labelled with mean values of particular traits. Genotypes, T186-1, T047-1, T-330-1 and T330-25 had high $\mathrm{K}^{+}$concentration in the seeds ranging from $13-14 \mathrm{~mol} / \mathrm{m}^{3}$ whereas, genotypes YS-2008, T267-7 and T312-12 were having relatively lower $\mathrm{K}^{+}$concentration in the seeds ranging from $9-10 \mathrm{~mol} / \mathrm{m}^{3}$. Genotypes T330-25 had relatively higher $\mathrm{Na}^{+}$concentration $\left(11.16 \mathrm{~mol} / \mathrm{m}^{3}\right)$ under stress free conditions whereas, genotype T312-11 $\left(7.25 \mathrm{~mol} / \mathrm{m}^{3}\right)$ and T312-14 $\left(7.25 \mathrm{~mol} / \mathrm{m}^{3}\right)$ had lowest $\mathrm{Na}^{+}$ concentration in the maize seeds (Fig. 1).

PCA biplot for $4 \mathrm{dS} / \mathrm{m}$ from experiment-1 presented the $100 \%$ (PC-1: $87.48 \%$, PC-2: $12.52 \%$ ) variability in the data of studied traits. genotype T267-6, SEEDCO and C863-68 have more than $12.00 \mathrm{~mol} / \mathrm{m}^{3} \mathrm{Na}^{+}$concentration in the seeds whereas, genotypes T330-25 and T330-10 were having lower $\mathrm{Na}^{+}$concentration ranging from $9.01 \mathrm{~mol} / \mathrm{m}^{3}$ to $9.64 \mathrm{~mol} / \mathrm{m}^{3}$ respectively. T330-10, T267-5 and YS-2008 were having higher $\mathrm{K}^{+}$concentration $\left(>10.00 \mathrm{~mol} / \mathrm{m}^{3}\right)$ whereas, genotypes T322-195 has lower $\mathrm{K}^{+}$concentration $\left(<9.50 \mathrm{~mol} / \mathrm{m}^{3}\right)$ in the seeds (Fig. 1).

PCA biplot for $6 \mathrm{dS} / \mathrm{m}$ from experiment-1 depicted the 99.99\% (PC-1: $62.21 \%$, PC-2: $37.78 \%$ ) variability from the raw mean data of studied traits. Biplot showed that trait vectors were widely distributed in the graph. Genotype YS$2008\left(\sim 12.00 \mathrm{~mol} / \mathrm{m}^{3}\right)$ had lowest $\mathrm{Na}^{+}$concentration whereas; genotypes C863-68, T312-14 and T267-5 had highest $\mathrm{Na}^{+}$concentration $\left(\sim 16.00 \mathrm{~mol} / \mathrm{m}^{3}\right)$ in the seeds. Genotype C864-228 had highest $\mathrm{K}^{+}$concentration $(\sim 10.00$ $\mathrm{mol} / \mathrm{m}^{3}$ ) whereas, genotypes C863-68 and C864-248 had the lowest $\mathrm{K}^{+}$concentration $\left(\sim 8.00 \mathrm{~mol} / \mathrm{m}^{3}\right)$ in the seeds (Fig. 1).

PCA biplot for $10 \mathrm{dS} / \mathrm{m}$ from experiment showed the 99.90\% (PC-1: $61.91 \%$ and PC-2: 37.99\%) variability from mean data for subjected traits. genotypes T312-14, T267-5, T267-6, T312-12 and YS-2008 had the highest $\mathrm{Na}^{+}$ concentration $\left(>18.00 \mathrm{~mol} / \mathrm{m}^{3}\right)$ in the seeds whereas genotypes C863-109 and C864-237 had the lowest $\mathrm{Na}^{+}$ concentration $\left(\sim 15.50 \mathrm{~mol} / \mathrm{m}^{3}\right)$ in the seeds at T-4 stress treatment. Genotypes C863-68, SEEDCO, T-330-1, C863109, T322-195 and C864-237 have relatively higher $\mathrm{K}^{+}$ concentration $\left(\sim 7.50 \mathrm{~mol} / \mathrm{m}^{3}\right)$ whereas, genotypes T312-11 and YS-2008 have relatively lower $\mathrm{K}^{+}$concentration $(\sim 5.50$ $\mathrm{mol} / \mathrm{m}^{3}$ ) in the seeds (Fig. 1).

PCA biplot for distilled water from experiment-2 showed the $80.59 \%$ (PC-1: 62.5\%, PC-2: 18.09\%) variability from the data of different germination, seedling and physiological traits (Fig. 2). Angle between the trait vectors was reflecting the correlation between the traits. Less than $90^{\circ}$ angle between the trait vectors is reflecting the positive correlation between the traits whereas, more than $90^{\circ}$ angle between the trait vectors is depicting the negative correlation between the subjected traits. However, presence of exactly $90^{\circ}$ angle between two trait vectors is reflecting that traits are independent of each other. Plumule length (PluL) was positively correlated with $\mathrm{Na}^{+}$ concentration in the seedlings whereas, it was negatively correlated with $\mathrm{K}^{+}$concentration in the seedlings as depicted by the angle between the trait vectors under distilled water. However, correlation among traits could be easily visualized from biplot graph by viewing the angle of trait vectors under distilled water (Fig. 2). Genotypes T047-1, T186-1, T-3301 , and $\mathrm{T} 330-25$ had relatively higher $\mathrm{K}^{+}$concentration $\left(>13.50 \mathrm{~mol} / \mathrm{m}^{3}\right)$ whereas, genotypes T312-11 and T267-7 had relatively lower $\mathrm{K}^{+}$concentration $\left(\sim 10.50 \mathrm{~mol} / \mathrm{m}^{3}\right)$ in maize seedlings. Genotypes T267-5, T283-30 and C864-237 had relatively higher $\mathrm{Na}^{+}$concentration whereas genotypes C863-109 and T312-12 had relatively lower $\mathrm{Na}^{+}$ concentration in seedlings under distilled water (Fig. 2).

PCA biplot for $4 \mathrm{dS} / \mathrm{m}$ from experiment-2 showed the 79.32\% (PC-1: $66.77 \%$, PC-2: 12.55\%) variability in the data for subjected traits. It can be seen from the biplot that PloL and $\mathrm{Na}^{+} / \mathrm{K}^{+}$were positively correlated with each other. RadL, $\mathrm{K}^{+}$concentration and FGP were positively correlated with each other. However, vector for $\mathrm{Na}^{+}$concentration was differently positioned on the biplot. Genotypes C863-68, T267-6 and C864-228 had relatively higher $\mathrm{Na}^{+}$ concentration $\left(>12.50 \mathrm{~mol} / \mathrm{m}^{3}\right)$ whereas, genotypes T330-10 and T330-25 had relatively lower $\mathrm{Na}^{+}$concentration $(\sim 9.50$ $\mathrm{mol} / \mathrm{m}^{3}$ ) in the seedlings at $4 \mathrm{dS} / \mathrm{m}$. Genotypes T267-5, C864-237 and YS-2008 had relatively higher $\mathrm{K}^{+}$ concentration $\left(\sim 11.00 \mathrm{~mol} / \mathrm{m}^{3}\right)$ whereas, genotypes T283-30 and T330-25 had lower $\mathrm{K}^{+}$concentration $\left(\sim 9.50 \mathrm{~mol} / \mathrm{m}^{3}\right)$ in 

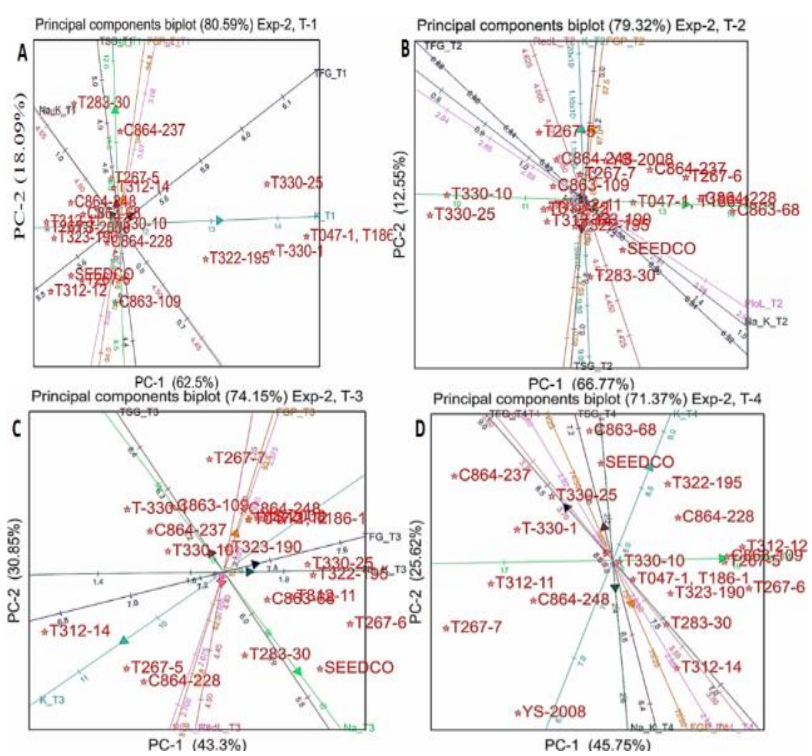

Fig. 2: PCA biplot analysis of different salinity treatments applied at early seedling stage in different maize genotypes (Experiment-2). (A): T-1 (distilled water), (B): T-2 (4 dS/m), (C): T-3 (6 dS/m), (D): T-4 $(10 \mathrm{dS} / \mathrm{m})$. Where, $\mathrm{Na}^{+}$: Sodium concentration $\left(\mathrm{mol} / \mathrm{m}^{3}\right), \mathrm{K}^{+}$: potassium concentration $\left(\mathrm{mol} / \mathrm{m}^{3}\right)$, $\mathrm{Na}^{+} / \mathrm{K}^{+}$sodium potassium ratio, TSG: time to start germination (days), TFG: time to $50 \%$ germination (days), FGP: final germination percentage $(\%)$, RadL: radicle length $(\mathrm{cm})$, PluL: plumule length $(\mathrm{cm})$

the seedlings at $4 \mathrm{dS} / \mathrm{m}$ (Fig. 2).

PCA biplot for $6 \mathrm{dS} / \mathrm{m}$ from experiment-2 showed the $74.15 \%$ (PC-1: $43.3 \%$, PC-2: $30.85 \%$ ) variability from the raw mean data of studied germination, seedling and physiological traits. Astonishingly $\mathrm{K}^{+}$concentration and $\mathrm{Na}^{+}$ concentration were not correlated among maize genotypes for this salinity treatment whereas, $\mathrm{Na}^{+}$concentration has weak positive correlation with $\mathrm{Na}^{+} / \mathrm{K}^{+}$ratio. Genotypes T330-1 and T267-7 had lowest $\mathrm{Na}^{+}$concentration ( 14.00 $\mathrm{mol} / \mathrm{m}^{3}$ ) whereas, genotypes T267-6, T283-30 and SEEDCO were having the higher relative concentration $\left(>16.00 \mathrm{~mol} / \mathrm{m}^{3}\right.$ ) of $\mathrm{Na}^{+}$ions. Genotypes T312-14, T2675 and $\mathrm{C} 864-228$ were having higher $\mathrm{K}^{+}$concentration $\left(>10.00 \mathrm{~mol} / \mathrm{m}^{3}\right)$ whereas, genotypes $\mathrm{T} 322-195$ and T330-25 were having lower $\mathrm{K}^{+}$concentration $(\sim 8.00$ $\mathrm{mol} / \mathrm{m}^{3}$ ) at $6 \mathrm{dS} / \mathrm{m}$ (Fig. 2).

PCA biplot for $10 \mathrm{dS} / \mathrm{m}$ from experiment-2 exhibited the $71.37 \%$ (PC-1: $45.75 \%$, PC-2: $25.62 \%$ ) variability of data for different studied traits. TSG, TFG, RadL and $\mathrm{K}^{+}$ concentration was positively correlated with each other whereas, $\mathrm{Na}^{+}$was not having strong positive or negative correlation with other traits. Genotypes C864-237 and T267-7 were having lowest $\mathrm{Na}^{+}$concentration $(\sim 16.00$ $\mathrm{mol} / \mathrm{m}^{3}$ ) relative to other genotypes whereas, genotypes T267-6, C863-109 and T312-12 were having higher $\mathrm{Na}^{+}$ concentration $\left(>18.50 \mathrm{~mol} / \mathrm{m}^{3}\right)$. Genotypes C863-68 and T322-195 were having higher $\mathrm{K}^{+}$concentration $(>8.50$ $\mathrm{mol} / \mathrm{m}^{3}$ ) whereas genotypes, T267-7 and YS-2008 were having lower $\mathrm{K}^{+}$concentration $\left(\sim 6.50 \mathrm{~mol} / \mathrm{m}^{3}\right)$ relative to other genotypes under $10 \mathrm{dS} / \mathrm{m}$ salinity treatment (Fig. 3).

PCA biplot for distilled water from experiment-3 exhibited the $65.11 \%$ (PC-1: $36.54 \%$, PC-2: 28.57\%) variation from the data of all of the studied traits. $\mathrm{Na}^{+}$ concentration and $\mathrm{Na}^{+} / \mathrm{K}^{+}$ratio were positively correlated with each other. SL and $\mathrm{K}^{+}$concentration were also positively correlated. RL was strong positively correlated with RFW whereas; SL was strong positively correlated with SFW. Genotypes YS-2008, T323-190 and T267-5 were having higher $\mathrm{Na}^{+}$concentration $\left(35.50-42.67 \mathrm{~mol} / \mathrm{m}^{3}\right)$ whereas genotypes C863-109 and T312-12 were having lower $\mathrm{Na}^{+}$concentration $\left(\sim 25.00 \mathrm{~mol} / \mathrm{m}^{3}\right)$ in the seedlings. Genotypes T267-6 and T322-195 were having higher $\mathrm{K}^{+}$ concentration $\left(\sim 140.00 \mathrm{~mol} / \mathrm{m}^{3}\right)$ whereas genotypes T33025 and YS-2008 were having lowest $\mathrm{K}^{+}$concentration $\left(\sim 122.50-130.00 \mathrm{~mol} / \mathrm{m}^{3}\right)$ under distilled water salinity treatment (Fig. 3).

PCA biplot for $4 \mathrm{dS} / \mathrm{m}$ from experiment-3 showed the $61.54 \%$ (PC-1: $37.57 \%$, PC-2: 23.98\%) variability from the data of different morphological, physiological and biochemical traits. Among studied genotypes, YS-2008 had the highest $\mathrm{Na}^{+}$concentration $\left(\sim 53.00 \mathrm{~mol} / \mathrm{m}^{3}\right)$ whereas, T330-10 were having lowest $\mathrm{Na}^{+}$concentration $(\sim 34.50$ $\left.\mathrm{mol} / \mathrm{m}^{3}\right)$. Among studied genotypes, C864-248 were having highest concentration $\left(\sim 130.00 \mathrm{~mol} / \mathrm{m}^{3}\right)$ of $\mathrm{K}^{+}$ions whereas, genotypes YS-2008 and T330-10 were having the lowest $\mathrm{K}^{+}$ concentration $\left(\sim 105.00 \mathrm{~mol} / \mathrm{m}^{3}\right)$ in seedlings (Fig. 3).

PCA biplot for $6 \mathrm{dS} / \mathrm{m}$ from experiment-3 reflected the $71.6 \%$ (PC-1: $48.37 \%$, PC-2: 23.24\%) variability of data from all of the studied traits. $\mathrm{K}^{+}$concentration was negatively correlated with $\mathrm{Na}^{+}$concentration, $\mathrm{Na}^{+} / \mathrm{K}^{+}$ratio and RFW. LT, TPB and SFW were positively correlated with each other. Among studied genotypes, T047-1, T186-1 and SEEDCO were having the highest $\mathrm{K}^{+}$concentration $\left(\sim 92.00 \mathrm{~mol} / \mathrm{m}^{3}\right)$ whereas; genotypes T312-14 and T267-7 were having lowest concentration $\left(\sim 75.00 \mathrm{~mol} / \mathrm{m}^{3}\right)$ of $\mathrm{K}^{+}$ ions in the seedlings. Genotypes, T047-1, T186-1 and T323190 were having lowest $\mathrm{Na}^{+}$concentration $\left(\sim 70.00 \mathrm{~mol} / \mathrm{m}^{3}\right)$ whereas; genotypes T322-195, C864-248, YS-2008 were having higher $\mathrm{Na}^{+}$concentration $\left(\sim 92.00 \mathrm{~mol} / \mathrm{m}^{3}\right)$ in the seedlings (Fig. 3).

PCA biplot for $10 \mathrm{dS} / \mathrm{m}$ from experiment-3 revealed the $66.97 \%$ (PC-1: $42.39 \%$, PC-2: $24.58 \%$ ) variability. LT, $\mathrm{Na}^{+}$concentration and $\mathrm{Na}^{+} / \mathrm{K}^{+}$were positively correlated with each other but these were negatively correlated with $\mathrm{K}^{+}$ concentration. $\mathrm{K}^{+}$concentration was positively correlated with SL, RL, SFW, RFW and TPB. Among studied maize genotypes, C863-68 and C864-248 were having higher $\mathrm{K}^{+}$ concentration $\left(\sim 42.00 \mathrm{~mol} / \mathrm{m}^{3}\right)$ whereas, genotypes T312-14 and YS-2008 were having lowest $\mathrm{K}^{+}$concentration $(\sim 25.00$ $\mathrm{mol} / \mathrm{m}^{3}$ ) in seedlings. Genotypes T267-7, T330-25 and C864-248 were having lowest $\mathrm{Na}^{+}$concentration $(\sim 124.00$ $\mathrm{mol} / \mathrm{m}^{3}$ ) whereas genotypes T-330-1 and YS-2008 were having highest concentration $\left(\sim 136.00-142.00 \mathrm{~mol} / \mathrm{m}^{3}\right)$ of 

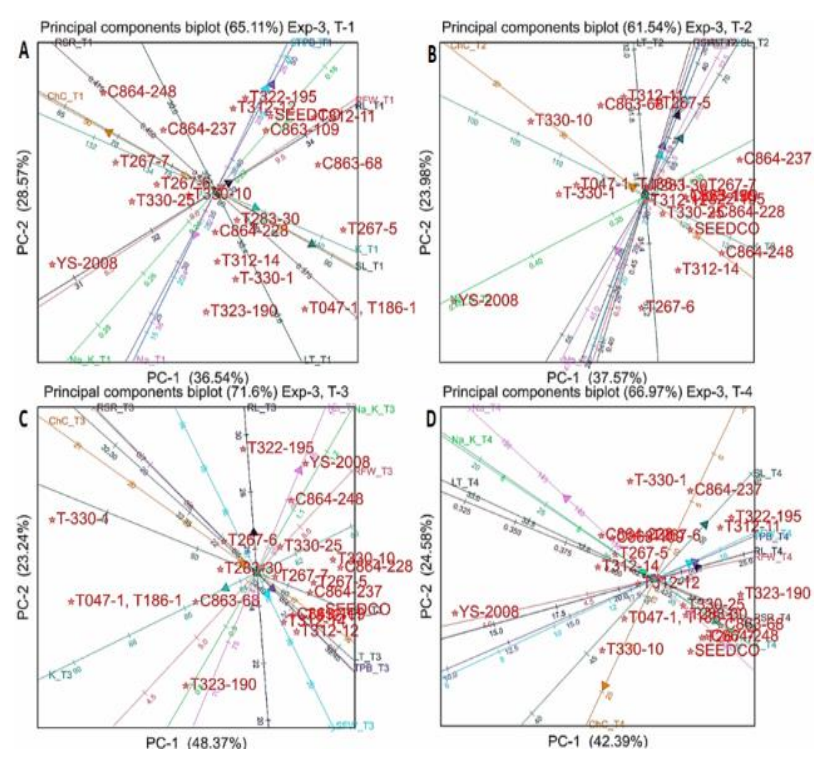

Fig. 3: PCA biplot analysis of different salinity treatments applied at seedling stage in hydroponic culture in different maize genotypes (Experiment-3). (A): T-1 (distilled water), (B): T-2 (4 $\mathrm{dS} / \mathrm{m}),(\mathbf{C})$ : T-3 (6 dS/m), (D): T-4 (10 dS/m). Where, $\mathrm{Na}^{+}$: Sodium concentration $\left(\mathrm{mol} / \mathrm{m}^{3}\right), \mathrm{K}^{+}$: potassium concentration $\left(\mathrm{mol} / \mathrm{m}^{3}\right), \mathrm{Na}^{+} / \mathrm{K}^{+}$sodium potassium ratio, SL: shoot length $(\mathrm{cm})$, $\mathrm{RL}$ : root length $(\mathrm{cm}), \mathrm{SFW}$ : shoot fresh weight $(\mathrm{g}), \mathrm{RFW}$ : root fresh weight $(\mathrm{g})$, TPB: total plant biomass $(\mathrm{g})$, LT: leaf temperature $\left({ }^{\circ} \mathrm{C}\right), \mathrm{ChC}$ : chlorophyll contents $\left(\mu \mathrm{mol} / \mathrm{m}^{2}\right)$

$\mathrm{Na}^{+}$ions in the seedlings (Fig. 3).

\section{GGE biplot analysis}

GGE comparison biplots for genotypes and treatments were made for visualization of best performing genotypes and theoretically ideal treatment combination particularly for $\mathrm{Na}^{+}$and $\mathrm{K}^{+}$concentrations. GGE biplot for $\mathrm{Na}^{+}$ concentration was reflecting the $63.90 \%$ (PC-1: $35.54 \%$, PC-2: $28.36 \%$ ) variability in the data across four different salinity treatments (Fig. 4). Genotypes present at the center of concentric circles were defined theoretically ideal for that particular traits if desirability for that trait is higher value. Otherwise, if desirability is lower value for particular trait like $\mathrm{Na}^{+}$then genotypes positioned farthest away from the center of concentric circles are preferably selected. Lower $\mathrm{Na}^{+}$concentration is indicative of tolerant behavior of genotypes therefore genotypes with lower or poor $\mathrm{Na}^{+}$ concentration are desirably selected.

In Experiment-1, genotypes T330-25, T312-11 and T330-10 were declared unanimously as tolerant due to locating farthest away from the center of concentric circles whereas, genotypes SEEDCO, T267-6, C864-228 and C863-68 were susceptible for being positioned at center of concentric circles. In Experiment-2, GGE biplot was depicting the $75.40 \%$ (PC-1: $45.74 \%$, PC-2: $29.66 \%$ ) variability and genotypes SEEDCO, C864-228 and T267-6 were susceptible whereas, genotypes T267-7, T330-1, T330-10 and T330-25 were tolerant based on their performance across all of the four salt stress treatments. In Experiment-3, GGE biplot was depicting the $75.15 \%$ (PC-1: 48.20\%, PC-2: $26.95 \%$ ) variability for $\mathrm{Na}^{+}$concentration across all of the four stress treatments. Genotype YS-2008 was highly susceptible whereas, genotypes T323-190, C863-68 and SEEDCO were tolerant across all of the four treatments based on having lowest $\mathrm{Na}^{+}$concentration even at higher stress treatment (Fig. 4).

GGE biplot for comparison of environments (blue colored concentric circles) were reflecting the same proportion of variability across the experiments as reflected by GGE biplots for genotypic comparison (green colored concentric circles) at $\mathrm{Na}^{+}$concentration. Based on the representativeness and discrimination power of the stress treatments for $\mathrm{Na}^{+}$concentration, stress treatments were ranked from theoretically ideal to poor treatment (Fig. 4) as following; Experiment-1: $4 \mathrm{dS} / \mathrm{m}>6 \mathrm{dS} / \mathrm{m}>10 \mathrm{dS} / \mathrm{m}>$ distilled water; Experiment-2: $6 \mathrm{dS} / \mathrm{m}>4 \mathrm{dS} / \mathrm{m}>10 \mathrm{dS} / \mathrm{m}$ $>$ distilled water; Experiment-3: $4 \mathrm{dS} / \mathrm{m}>$ distilled water $>6$ $\mathrm{dS} / \mathrm{m}>10 \mathrm{dS} / \mathrm{m}$.

GGE biplot for genotypic comparison was reflecting the $81.30 \%$ (PC-1: $55.46 \%$, PC-2: $25.84 \%$ ) variability for $\mathrm{K}^{+}$concentration in Experiment-1. Higher the $\mathrm{K}^{+}$ concentration in genotypic samples is reflecting the higher level of tolerance against salt stress. In Experiment-1, genotypes T267-5, T322-195 and T330-1 were theoretically ideal for having higher $\mathrm{K}^{+}$concentration across the four different treatments whereas, genotypes YS-2008 was poor for having lower $\mathrm{K}^{+}$concentration. In Experiment-2, genotypes T-330-1, T267-5, C864-228 and C864-237 were theoretically ideal whereas, genotypes YS-2008, T267-6 and T312-12 were poor in performance. In Experiment-3, genotypes T323-190, C864-237 and SEEDCO were better performing whereas, genotypes TS-2008, T330-10 and T330-25 were poor performing across the subjected salinity treatments (Fig. 5).

Based on the representativeness and discrimination power of the stress treatments for $\mathrm{K}^{+}$concentration, stress treatments were ranked from theoretically ideal to poor treatments (Fig. 5) as following; Experiment-1: $10 \mathrm{dS} / \mathrm{m}>$ distilled water $>6 \mathrm{dS} / \mathrm{m}>4 \mathrm{dS} / \mathrm{m}$; Experiment-2: distilled water $>6 \mathrm{dS} / \mathrm{m}>10 \mathrm{dS} / \mathrm{m}>4 \mathrm{dS} / \mathrm{m}$; Experiment-3: $4 \mathrm{dS} / \mathrm{m}$ $>10 \mathrm{dS} / \mathrm{m}>6 \mathrm{dS} / \mathrm{m}>$ distilled water.

\section{Discussion}

Dissection of variability into discrete components showed that genotypic responses, treatment effects and genotype by environment interaction effects were significantly different for studied traits from seedling developed in petri plates and hydroponic studies. It is evidently proved that maize genotypes showed the differential responses to different salinity treatments at different stages and these findings have support from several other researchers (Schubert et al. 

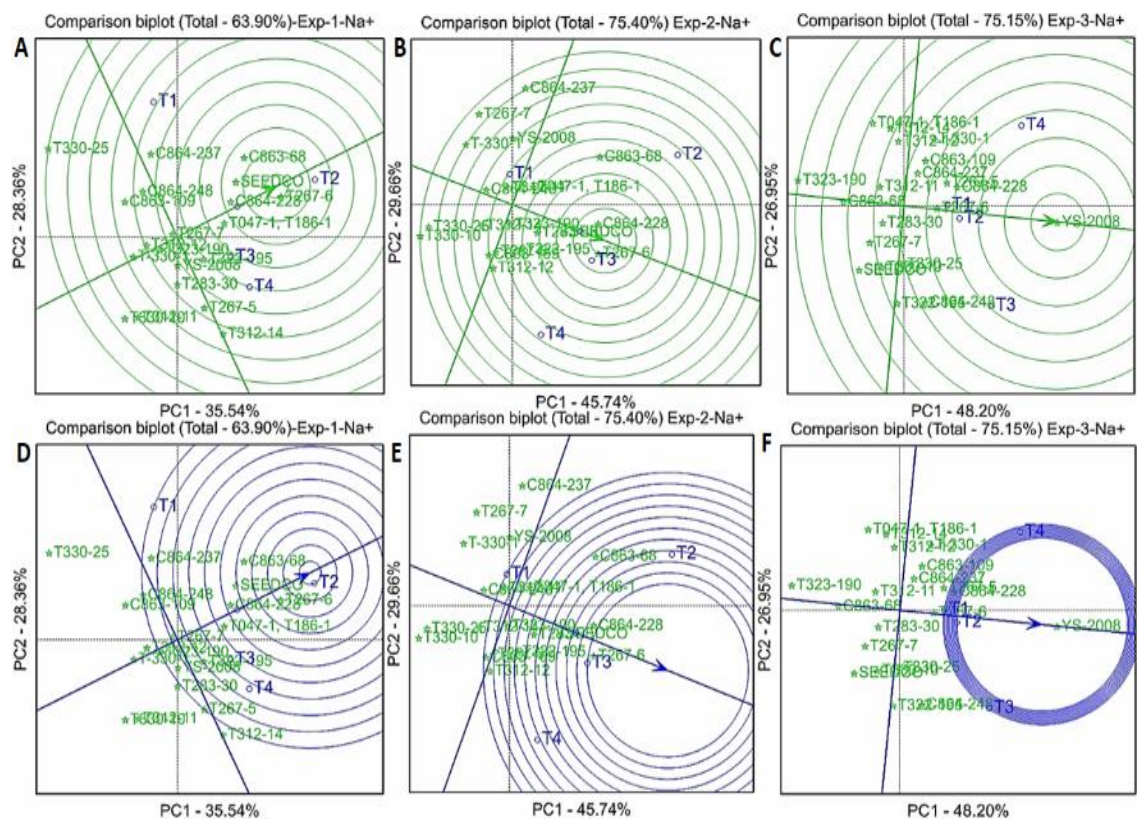

Fig. 4: GGE biplot analysis for Na+ concentration of different maize genotypes under different salinity treatments from three different experiments. (A): Genotype comparison biplot for Experiment-1, (B): Genotype comparison biplot for Experiment-2, (C): Genotype comparison biplot for Experiment-3, (D): environment comparison biplot for Experiment-1, (E): environment comparison biplot for Experiment-2, (F): environment comparison biplot for Experiment-3. Where, T1: distilled water, T2: 4 dS/m, T3: 6 dS/m, T4: 10 dS/m

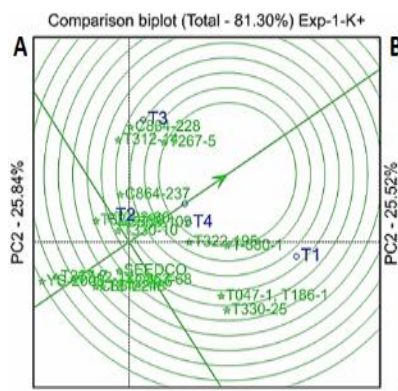

PC1 - 55.46\% Comparison biplot (Total - $81.30 \%)$ Exp-1-K+

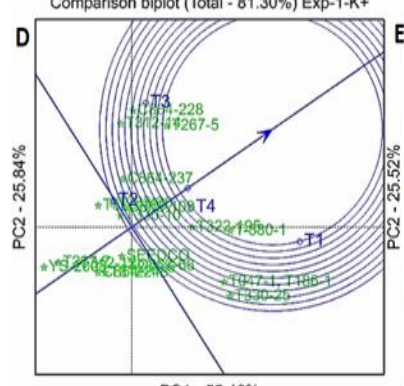

PC1 $-55.46 \%$

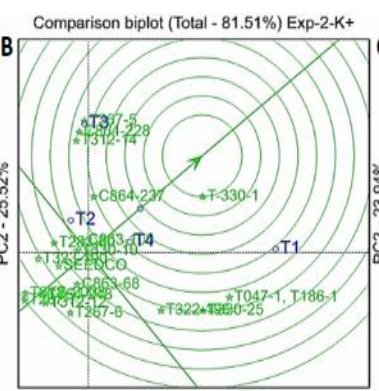

PC1 - $55.99 \%$
Comparison biplot (Total - $81.51 \%)$ Exp-2-K+

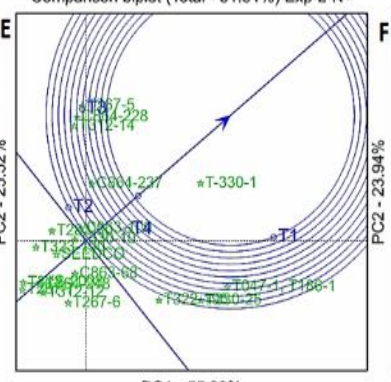

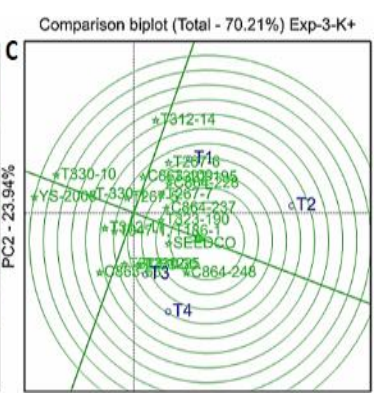

$\mathrm{PC1}-46.28 \%$
Comparison biplot (Total - $70.21 \%)$ Exp-3-K+

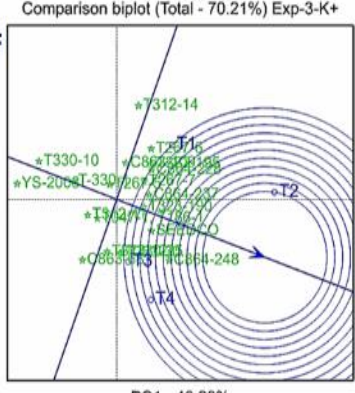

Fig. 5: GGE biplot analysis for $\mathrm{K}^{+}$contents of maize genotypes under different salinity treatments from three different experiments. (A): Genotype comparison biplot for Experiment-1, (B): Genotype comparison biplot for Experiment-2, (C): Genotype comparison biplot for Experiment-3, (D): environment comparison biplot for Experiment-1, (E): environment comparison biplot for Experiment-2, (F): environment comparison biplot for Experiment-3. Where, T1: distilled water, T2: 4 dS/m, T3: 6 dS/m, T4: $10 \mathrm{dS} / \mathrm{m}$

\section{9; Richter et al. 2015).}

Current study showed that imbibition of $\mathrm{Na}^{+}$was higher than $\mathrm{K}^{+}$with the increase of level of salt stress. $\mathrm{Na}^{+} / \mathrm{K}^{+}$ratio was also increased in imbibed seeds which indicate that $\mathrm{Na}^{+}$uptake was increasing with the increase in level of salt stress. Similar trend was observed in germinated seeds and plumule parts in Experiment-2. Seedlings in hydroponic culture also showed the similar trend of increased $\mathrm{Na}^{+}$concentration in seedlings compared to $\mathrm{K}^{+}$ concentration under increasing level of salt stress. The 
$\mathrm{Na}^{+} / \mathrm{K}^{+}$ratio was also increased which indicate that $\mathrm{Na}^{+}$ uptake is increased with increased level of salt stress and resultantly toxic effects of $\mathrm{Na}^{+}$are evidently expressed. Seed germination basically comprised of three phases i.e., imbibition, lag phase and radicle growth \& emergence. Higher $\mathrm{Na}^{+}$uptake through imbibition prolongs the lag phase and resultantly germination was delayed or prevented (Tian et al. 2014). Sodium is reported to be the principle toxic ion for maize which is inducing the toxicity and also disturbing the potassium uptake and transport, impairing the stomatal functioning and causing necrosis in the maize genotypes (Neto and Tabosa 2000; Farooq et al. 2015). Differential $\mathrm{Na}^{+}$uptake by different genotypes and inhibitory effects on the germination of seeds has been reported by large number of researchers (Hasegawa et al. 2000; Farsiani and Ghobadi 2009).

As it was observed in Experiment-1, that accumulation of $\mathrm{Na}^{+}$ions was increased in seeds through imbibition which may affect the germination and this query was answered by Experiment-2. Experiment-2 showed that germination related traits like time to start germination (4.7 days to 6.8 days) and time to $50 \%$ germination (5.7 days to 7.9 days) were increased whereas, final germination percentage $(94 \%$ to $75 \%$ ), radical length (4.6 com to $3.6 \mathrm{~cm}$ ) and plumule length $(3.7 \mathrm{~cm}$ to $2.3 \mathrm{~cm})$ were decreased. It is reported that salt stress is affecting the seed germination and related traits like, time to start germination, germination rate and increased distortion in germination events (Ashraf and Foolad 2005; Janmohammadi et al. 2008). Effect of salt stress on maize seed germination and other related traits may be attributed to reduced osmotic potential, sodium and/or chloride ion toxicity to embryo or by changes in protein biosynthesis. It is also reported that osmotic stress and toxic effects of sodium ions may delay or inhibit the seed germination (Ashraf and Foolad 2005; Janmohammadi et al. 2008). Delayed or decreased germination may be attributed to lowered osmotic potential, reduced water uptake and sodium toxicity to the embryos. Therefore, integration of osmotic stress and ionic toxicity by imposition of higher level of salinity stress results in suppressed or delayed germination (Hasegawa et al. 2000; Farsiani and Ghobadi 2009; Farooq et al. 2015) Researchers also mentioned that germination and early growth stages are highly sensitive to salt stress (Farooq et al. 2015) therefore, evaluation of maize genotypes under salt stress at early growth stages in prerequisite and same was done in this study.

Hydroponic study revealed that root length, shoot length, shoot fresh weight, root fresh weight, total plant biomass and chlorophyll contents were reduced by increasing the severity of salt stress from tap water to 10 $\mathrm{dS} / \mathrm{m}$ stress. Leaf temperature was intended to increase in the genotypes by increasing the concentration of salinity stress. Vegetative growth is reduced by salinity stress due to suppression of leaf initiation, intermodal growth and cell cycle of meristematic tissues (Akram et al. 2010; Qu et al. 2012). Root is directly exposed to saline environment either in the hydroponic or field conditions. Root growth is suppressed either due to low osmotic potential and ionic toxicity which may reduce the cell division and cell expansion by modulating the gene expression. Reduction is photosynthetic activity is also one of the key factors for reduced growth under salinity stress (Farooq et al. 2015) as it is also evident in present study that chlorophyll contents of the maize genotypes were reduced with the increase of salt stress.

Visual presentation of results provides better understanding of responses of genotypes to stress conditions. For the said purpose, one of the most used multivariate analysis "PCA biplot analysis" was used in present. PCA biplot has been widely used by several researchers for understanding the genotypic responses of different crop plants under different stresses (Aslam et al. 2016, 2017). Genotypes with poor performance at distilled water were defined as susceptible, genotypes having better performance at $4 \mathrm{dS} / \mathrm{m}$ were described as moderately susceptible and genotypes with better performance at 6 $\mathrm{dS} / \mathrm{m}$ were declared to be moderately tolerant whereas, genotypes having better performance at $10 \mathrm{dS} / \mathrm{m}$ were defined as tolerant against the salinity stress at early growth stages. Based on these prospects, assortation of genotypes was made by PCA biplot and briefly describing the categorical performance of genotypes; susceptible genotypes from Experiment-1 were T312-12, T267-7 \& YS-2008; from Experiment-2, T283-30, C864-237 \& T2675, and from Experiment-3: T267-5, YS-2008 and T323-190. Moderately susceptible genotypes from Experiment-1: T267-7, T312-12, \& SEEDCO; from Experiment-2: C864237, T283-30 \& T-267-5 and from Experiment-3: YS-2008, C864-248 and T267-7. Moderately tolerant genotypes from Experiment-1 were T267-7, T312-12 and T267-6; from Experiment-2 were T330-25, T322-195 \& T312-12 and from Experiment-3 were T047-1, T186-1, SEEDCO and C863-68. Tolerant genotypes from Experiment-1 were T312-11, C863-109 and C864-237; from Experiment-2 were YS-2008, T267-7 and C864-284 and from Experiment-3 were C863-68 and C864-248. It can be seen that PCA biplots discriminated the genotypes based on performance for all traits for each of the stress treatment separately. PCA biplot is preferably being used for selection of genotypes depending upon research objectives (Aslam et al. 2016, 2017).

Evaluation of the genotypic performance interactive of all stress treatments was necessary to prioritize the genotypes and identification of discriminating environments for conducting further studies against salinity stress at early growth stages. Therefore, GGE biplot analysis (Yan and Tinker 2006) was used in present studies to identify the ideal genotypes (best in performance) and ideal environment (most representative and most discriminating). GGE biplots explained 63 to $81 \%$ variability for $\mathrm{Na}^{+}$and $\mathrm{K}^{+}$ traits across four different salinity treatments. This proportion of variability contribution was justified enough 
to extract practically applicable results (Yan and Tinker 2006; Maqbool et al. 2015). SEEDCO genotype was noted to be susceptible against salinity stress for germination and early seedling stages but it was stress tolerant in the hydroponic studies. Genotype YS-2008 found to be susceptible to salinity stress across all of the three different studies. T323-190 was also tolerant against salinity stress under hydroponic studies. T330-25 was tolerant against salinity stress under implication of seed treatments and seedling growth under prevalence of salt solutions. However, many genotypes showed the tolerance at germination but susceptibility in hydroponic studies and vice versa. This type of results are very well explaining that different type physiological mechanisms are working at different growth stages therefore genotypes are conferring the differential responses against salinity stresses at different growth stages (Yan and Tinker 2006; Maqbool et al. 2015). At seed treatment and early seedling growth stages mild stress treatments were sufficient enough to discriminate the genotypes whereas, under hydroponic studies discrimination of genotypes requires the imposition of severe salt stress.

\section{Conclusion}

Different levels of salinity stress seriously affected the performance of maize genotypes at early growth stages. $\mathrm{Na}^{+}$ concentration was increased in seeds and seedlings of maize genotypes whereas; $\mathrm{K}^{+}$concentration was reduced by increasing the severity of salinity stress. YS-2008 was susceptible for seed treatment and hydroponic studies whereas, T267-5 was susceptible for early seedling and hydroponic studies. C864-284 was tolerant in early seedling and hydroponic studies. Under hydroponic conditions, genotypes could effectively be discriminated by the imposition of severe salt stress $10 \mathrm{dS} / \mathrm{m}$. However, under seed treatments and early seedling growth stages, mild stress treatments $4 \mathrm{dS} / \mathrm{m}$ were sufficient enough to discriminate the maize genotypes. Identified tolerant and susceptible genotypes could be effectively used in different breeding programs to develop salt tolerant new cultivars for commercial purposes.

\section{Acknowledgements}

We acknowledge the team of Soil Chemistry Lab, Institute of Soil and Environmental Sciences, University of Agriculture Faisalabad, Pakistan who help a lot for various lab analyses in this study.

\section{Author Contributions}

MA supervised the study and also contributed in planning, conducting of study, data analysis and manuscript write up, MAM analyzed the data, and prepared the manuscript, SA, WA, MAA and AA contributed in study layout, execution, data collection and lab analysis.

\section{Conflicts of Interest}

Authors declare no conflict of interest.

\section{Data Availability}

We hereby declare that data related to this article, are available with the corresponding author and will be produced on demand.

\section{Ethics Approval}

Ethical approval is not applicable in this study.

\section{References}

Acosta-Motos JR, MF Ortuño, A Bernal-Vicente, P Diaz-Vivancos, MJ Sanchez-Blanco, JA Hernandez (2017). Plant responses to salt stress: Adaptive mechanisms. Agronomy 7; Article 18

Akram M, MY Ashraf, R Ahmad, M Rafiq, I Ahmad, J Iqbal (2010). Allometry and yield components of maize (Zea mays L.) hybrids to various potassium levels under saline conditions. Arch Biol Sci Belgr 62:1053-1061

Ashraf M, MR Foolad (2005). Pre-sowing seed treatment-a shotgun approach to improve germination growth and crop yield under saline and none-saline conditions. Adv Agron 88:223-271

Aslam M, MA Maqbool, QU Zaman, M Shahid, MA Akhtar, AS Rana (2017). Comparison of different tolerance indices and PCA biplot analysis for assessment of salinity tolerance in lentil (Lens culinaris L.) genotypes. Intl J Agric Biol 19:470-478

Aslam M, MA Maqbool, QU Zaman, MA Akhtar (2016). Phenotypic indicators-based grouping of mungbean (Vigna radiata $\mathrm{L}$. Wilczek) genotypes under saline conditions using $K$-mean cluster analysis. $J$ Agric Basic Sci 1:37-44

Association of Official Seed Analysts (1990). Rules for testing seeds. J Seed Technol 12:101-112

Coolbear P, A Francis, D Grierson (1984). The effect of low temperature pre-sowing treatment under the germination performance and membrane integrity of artificially aged tomato seeds. J Exp Bot 35:1609-1617

ESP - Economic Survey of Pakistan (2019-2020), p:29. Federal Bureau of Statistic, Islamabad, Pakistan

Farooq M, N Gogoi, M Hussain, S Barthakur, S Paul, N Bharadwaj, HM Migdadi, SS Alghamdi, KHM Siddique (2017). Effects, tolerance mechanisms and management of salt stress in grain legumes. Plant Physiol Biochem 118:199-217

Farooq M, M Hussain, A Wakeel, KHM Siddique (2015). Salt stress in maize: Effects, resistance mechanisms, and management. Agron Sustain Dev 35:461-481

Farooq M, SMA Basra, K Hafeez, N Ahmad (2005). Thermal hardening: A new seed vigor enhancement tool in rice. J Integr Plant Biol 47:187-193

Farsiani A, ME Ghobadi (2009). Effects of PEG and $\mathrm{NaCl}$ stress on two cultivars of corn (Zea mays L.) at germination and early seedling stages. World Acad Sci Eng Technol 57:382-385

Foolad MR, GY Lin (2001). Relationships between cold and salt tolerance during seed germination in tomato: Analysis of response and correlated response to selection. J Amer Soc Hortic Sci $126: 216-220$

Gabriel KR (1971). The biplot graphic of matrices with application to principal component analysis. Biometrics 58:453-467

Gao Y, Y Lu, M Wu, E Liang, Y Li, D Zhang, Z Yin, X Ren, Y Dai, D Deng, J Chen (2016). Ability to remove $\mathrm{Na}^{+}$and retain $\mathrm{K}^{+}$correlates with salt tolerance in two maize inbred lines seedlings. Front Plant Sci 7; Article 1716 
Hasegawa PM, RA Bressan, JK Zhu, HJ Bohnert (2000). Plant cellular and molecular response to high salinity. Annu Rev Plant Physiol Plant Mol Biol 51:463-499

Hoagland DR, DI Arnon (1950). The water culture method for growing plants without soil. California Agricultural Experiment Station Circular No. 347, $2^{\text {nd }}$ edn, p:39. University of California Berkeley, USA

Hussain M, S Ahmad, S Hussain, R Lal, S Ul-Allah, A Nawaz (2018). Rice in saline soils: Physiology, biochemistry, genetics and management. Adv Agron 148:231-287

Hussain M, HW Park, M Farooq, K Jabran, DJ Lee (2013). Morphological and physiological basis of salt resistance in different rice genotypes. Intl J Agric Biol 15:113-118

ISTA (2008). The germination test, chapter 5. Seed Testing, pp:104-106. International Seed Testing Association, Zurich, Switzerland

Janmohammadi M, PM Dezfuli, F Sharifzadeh (2008). Seed invigoration techniques to improve germination and early growth of inbred line of maize under salinity and drought stress. Gen Appl Plant Physiol 34:215-226

Maqbool MA, M Aslam, H Ali, TM Shah, BM Atta (2015). GGE biplot analysis-based selection of superior chickpea (Cicer arietinum L.) inbred lines under variable water environments. Pak J Bot 47:1901-1908

Mengel K, EA Kirby (2001). Principles of Plant Nutrition, $5^{\text {th }}$ edn. Kluwer Academic Publishers, Dordrecht, The Netherlands

Nawaz K (2007). Alleviation of the adverse effects of salinity stress on maize (Zea mays L.) by exogenous application of glycine betaine. M.Phil. Thesis. University of Agriculture, Faisalabad, Pakistan

Neto ADA, JN Tabosa (2000). Salt stress in maize seedlings: II Distribution of cationic macronutrients and its relation with sodium. Rev Bras Eng Agric Amb 4:165-171

Qu C, C Liu, X Gong, C Li, M Hong, L Wang, F Hong (2012). Impairment of maize seedling photosynthesis caused by a combination of potassium deficiency and salt stress. Environ Exp Bot 75:134-141
Rahman M, SA Kayani, S Gul (2000). Combined effects of temperature and salinity stress on corn cv. sunahry. Pak J Biol Sci 3:1459-1483

Richter JA, A Erban, J Kopka, C Zorb (2015). Metabolic contribution to salt stress in two maize hybrids with contrasting resistance. Plant Sci 233:107-115

Schubert S, A Neubert, A Schierholt, A Sumer, C Zorb (2009). Development of salt resistant maize hybrids: The combination of physiological strategies using conventional breeding methods. Plant Sci 177:196-202

Shahzad M, K Witzel, C Zorb, KH Muhling (2012). Growth-related changes in subcellular ion patterns in maize leaves (Zea mays L.) under salt stress. J Agron Crop Sci 198:46-56

Steel RGD, JH Torrie, DA Dickey (1997). Principles and Procedures of Statistics: A Biometrical Approach, $3^{\text {rd }}$ edn, pp:352-358. McGraw Hill, Inc. Book Co., New York, USA

Syed A, G Sarwar, SH Shah, S Muhammad (2021). Soil salinity research in $21^{\text {st }}$ century in Pakistan: Its impact on availability of plant nutrients, growth and yield of crops. Commun Soil Sci Plant Anal 52:183-200

Tian Y, B Guan, D Zhou, J Yu, G Li, Y Lou (2014). Responses of seed germination, seedling growth and seed yield traits to seed pretreatment in maize (Zea mays L.). Hindawi 2014 Article 834630

Turan MA, AHA Elkarim, N Taban, S Taban (2009). Effect of salt stress on growth, stomatal resistance, proline and chlorophyll concentrations on maize plant. Afr J Agric Res 4:893-897

Ul-Allah S, M Ijaz, A Nawaz, A Sattar, A Sher, M Naeem, U Shahzad, U Farooq, F Nawaz, K Mahmood (2020). Potassium application improves grain yield and alleviates drought susceptibility in diverse maize hybrids. Plants 9; Article 75

Wolf B (1982). The comprehensive system of leaf analysis and its use for diagnosting crop nutrient status. Commun Soil Sci Plant Anal 3:1035-1059

Yan W, NA Tinker (2006). Biplot analysis of multi-environment trial data: Principles and applications. Can J Plant Sci 86:623-645 